\title{
Understanding Somali Conflict: Causes, Consequences and Strategies for Peace-Building
}

\author{
Zakarie ABDI BADE \\ PhD Candidate, Ankara Yıldırım Beyazıt University, Graduate School of Social Sciences, Department of \\ Sociology Ankara, Turkey \\ Abdifatah ABDI HARED \\ PhD Candidate, Ankara Yıldırım Beyazıt University, Graduate School of Social Sciences, Political Science and \\ Public Administration, Ankara, Turkey
}

\begin{abstract}
Over the past decades, Somalia has experienced civil wars, inter-clan conflicts, militias warlords, terrorism, and other several violent conflicts. These conflicts resulted in the deaths of many innocent civilians and destroyed the state institutions, structures, and trust in governance and consequently affected the agricultural production of the country, which resulted to nationwide famine. Thus, this article aims to critically understand the causes and consequences of the conflict in Somalia. It also aims to discuss opportunities and strategies for peacebuilding and reconstruction of Somalia. The article reveals that clan and clannism are the leading causes of Somalia's destabilization. Furthermore, the article argues that radical extremism, corruption, the militarization of clan members, inequalities and extreme poverty, and massive youth unemployment are the most common factors that lead to Somalia's never ending conflict. On the other hand, this article examined that mass migration, extremism, the emergence of piracy, and the loss of Somali unity and nationalism are the results of the prolonged conflict. Moreover, the article found that the previous peacebuilding approaches such as the promotion of democracy, elections, free market-based reforms, and building local institutions combined with modern state standards adopted from the international community have failed to promote peace and stability in Somalia. Thus, this article recommends that social reconciliation should be held and led by the local people. This in return, we believe will help Somalia to restore peace, the rule of law and ensure long term stability.
\end{abstract}

Keywords: Conflict, Peacebuilding Efforts, Somalia, Challenges, Prospects.

DOI: $10.7176 / \mathrm{DCS} / 11-3-05$

Publication date:March $31^{\text {st }} 2021$

\section{Introduction}

The Somali state established in 1960 was the product of unifying the former British Somaliland which gained its independence from Britain on $26^{\text {th }}$ June 1960, and the former U.N. trust territory under Italian administration which gained its independence on $1^{\text {st }}$ July 1960, from Italy. Five days later, the two entities voluntarily united to form the Somali Republic on $1^{\text {st }}$ July 1960. This unification brought unity followed the adoption of a democratic system of government based on parliament democracy, although Somalia lacked the human resources, culture, and institutional bases necessary for the success of this system (Lewis, 1980). The democratic system guaranteed political parties the freedom to organize and to compete for national elections. Thus, Somalia became a democratic country with all citizens having the right to vote and stand as a candidate, freedom of associations was allowed, and two parliamentary and presidential elections were held. Moreover, Somalia enjoyed nine years of parliamentary democracy, arguably producing the first peaceful democratic transfer of power in Africa. This also marks Somalis president Adam Abdulle Osman to became the first African head of state to step down after losing national elections and end his seven years in office (Samatar, 2016).

However, a few years later, the democratic environment and the idea of political parties reflected clan loyalties which caused the dream of democracy not to live long. Moreover, self-rule, corruption, poverty, and insecurity paralyzed the newly established democratic institutions. Then, the situation became worse when the military regime led by Mohamed Siyad Barre overthrew the emerging of civilian government in a bloodless coup in 1969. The regime immediately changed the form of governance system from democratic rule to Leninist-Marxist style of governance and brought an abrupt end to the process of constitutional democracy. The regime administration reflected both ideological and economic dependence on the Soviet Union. Nevertheless, after twenty-one years of dictatorial rule and abuse of basic human rights, the military government was violently outset from power by various political unions and clan motivated rebel groups in 1991 (Elmi, 2010). Nonetheless, after the overthrow of the regime, no alternative authority was available to replace the regime, and the country immediately plunged into a state of anarchy and devastation (Abdi, 2012).

The plunge of the Siyad Barre regime triggered the emergence of civil war, armed groups, inter-clan conflicts, warlords, pirate gangs, and Islamist extremists which led to the annihilation of the structure of the government and its institutions which also caused the ruin of both human and material resources. Moreover, the conflict produced 
more than two million people displaced internally, and dozens immigrated to foreign countries (Avis \& Herbert, 2016). Thus, Somalia experienced absence a functioning strong central government since the collapse of the Siyad barre regime was ousted in 1991, making it the longest-running instance of complete state collapse in postcolonial history (Menkhaus, 2007).

Various peacebuilding and reconstruction efforts have been made for the last thirty years aimed at ending the hostilities and establishing a functional central government. So far there have been more than fifteen peacebuilding efforts, including many sponsored United Nations Mission in Somalia. Regional organizations such as IGAD also made several efforts to bring the Somalia conflict to an end through a peaceful process (Mulugeta, 2010). Somali's neighbour countries have also contributed to Somali's peacebuilding and reconstruction process. The most prominent national conference was held at Art, Djibouti in 2000 and 2004 Nairobi, peace conference. None of these efforts, however, has reached the desired results (Khayre, 2017).

Similarly, the international community has made numerous attempts to establish a central government and bring back stability to Somalia. For instance, in 1992, the United Nations security council (UNSC) approved a unilateral U.N. military intervention to Somalia (Harper, 2012). United Nations operations failed to restore peace and stability in Somalia (DiPrizio, 2002). Even though in 2004 a transitional government was established in Nairobi. In 2012 Somalia, completed its political transition through a limit and indirect election of a new federal parliament and president with the support of the international community. However, peacebuilding efforts have been challenged by internal conflict actors, financial challenges, and external actors (Harper, 2012). Therefore, this article concentrated on studying the nature of the Somali conflict. The article also seeks to establish the root causes and the consequences of the Somali conflict, and analysis strategies and opportunities for peacebuilding and reconstruction in Somalia. The next section of the study discusses the background of the conflict in Somalia.

\section{Conflict Background}

Bad governance practices and inequalities between members of various groups in terms of their access to political power and resources in the 1980s led to the emergence of armed clan-based movements that forced the Siyad Barre regime to flee the country following the collapse of the state in 1991. Since then, Somalia has been in a failed situation. Following this, a various grouping of armed factions sought to control the national territory of Somalia; thus, the country entered decades of prolonged conflict and civil war (Elmi \& Barise, 2006).

Furthermore, in the absence of authority, the clan-rebel groups that overthrew the Siyad Barre regime immediately fought one another to control Somalia. Other armed groups fought for controlling the capital city and established government. Ali Mahdi was appointed as interim president by residents in Mogadishu to lead the civilian wing of the U.S.C. However, General Aided who played a leading role in the fight against Siyad Barre annoyed the nomination of Ali Mahdi as a president. Nevertheless, Aided rejected Ali leadership and claimed he is the rightful person to lead Somalia. In 1991 several attempts aimed to reconcile these two rival groups were held in Djibouti; however, this attempt was a missed opportunity. Thus, a destructive fight broke out between General Aided and his rival Ali Mahdi which claimed the lives of as many as 25,00 innocent civilians and caused the death station of material resources (Clark, 1993). Moreover, this destructive battle divided the capital city of Mogadishu into two parts: an area controlled by Ali Mahdi, such as north of the city. At the same time, general Aided controlled other areas in the south, such as the airport and seaport (Abdi, 2012).

Amid this confusion, northern Somalia (currently known as Somaliland) declared political independence from the rest of Somalia under a government led by Somali National Movement (S.N.M.). Northern Somalia then became the self-declared Republic of Somaliland on $18^{\text {th }}$ May 1991. Whereas southern Somalia descended into a state of anarchy and fighting involving multiplication of numbers of clan-based warlords and militias as well as extremist fighters, which has to this date continued to hamper the re-establishment of the normal functioning of the nation-state structure.

Moreover, the civil war, which started between 1991 and 1992 in the south of the country destroyed the state institutions, structures, and trust in governance and consequently the agricultural production of the country which resulted in nationwide famine. An estimated 300.000 Somalis died from starvation. To control the problem, the international community adopted a resolution called 733; in 1992, this resolution was the first attempt to restore peace and stability and to reach people who are in need in Somalia. However, the Warlords disregarded the ceasefire and engaged in extensive fighting as well as looted international aid. Thus, this effort has not reached the desired result. Furthermore, Somalia tested ten years without government from (1991-2000), during this period many innocent civilians lost their lives because of the power and resource control struggle between the armed groups and/or the warlords. Whereas many other civilians lost their lives due to starvation and hunger. A review of literature has shown that, Mogadishu battle as one of the most controversial conflicts in half of the twentieth century. During this war, a Blackhawk helicopter was shot down by the rebel militia groups (New York Times, 1993). Likewise, this conflict marked the first time that two U.S. helicopters were shut down over Somali airspace, which finally led the U.S. to end its mission to Somalia in 1995 formally.

In 2000, the Transitional national government was established as Somalia's central government with 
Abdiqasim S. Hassan elected as the president after nine years of chaos. During his time into the office, his administration was able to control just parts of the Mogadishu, with the rest of the country, was under various faction leaders. Nevertheless, another attempt of peacebuilding and reconstruction was adopted when a transitional federal government was established in 2004 under the presidency of Abdullahi Yusuf Ahmed, with the support of the United Nations and the African Union. The transitional government was unable to promote reconciliation and set about peacebuilding and state-building strategies and was beset by an internal disagreement which resulted in transitional federal institutions to sat Baidoa in Southern Somalia and was incapable of reopening state institutions in the capital city of Mogadishu. Therefore, the competition of power and resources among different clans, the extremist organization, youth unemployment, and the unlimited foreign interventions made attempts to peacebuilding and conflict resolution in Somalia impossible (Elmi \& Barise, 2006).

Islamic Courts Union (U.I.C.) emerged in southern Somalia as a social movement, they have been active from 2004 to 2008 and had social and political aims reflecting both internal diversity (and division) and new international positioning (Abbink et al., 2009). The Islamic Courts movement enjoyed a significant level of support from the local people when they restored peace and stability in the countries' capital and their role in hunting down the 'War Lords' and Somalia reconstruction. Thus, during its six months in power, the Islamic Court Union achieved an unprecedented level of security in Mogadishu (Prendergast \& Thomas-Jensen, 2007).

The Islamic Courts were against the Transitional Federal Government of Somalia as their potential rival and declared a jihad against it. The severe confrontation between the Transitional Federal Government of Somalia and The Islamic Courts commenced a new phase of the Somali conflict which led Ethiopian militaries with the support of the U.S. intervened in Somalia to weaken Islamist militant groups.

However, the most extreme members within the Islamic Courts called themselves as Al-Shabaab and managed to control most of the capital and made the government to seek help from the African Union. Al-Shabaab, the Al-Qaida linked group carry out massive explosions, and suicides against the government of Somalia. This chaos leads to the arrival of peacekeeping forces from the African Union (AMISOM) ${ }^{1}$ from the Somali conflict and contributed to the justification of extremists to defend their country against foreign interventions. The radical extremists added the Somali conflict into another layer, terrorism, which claimed the lives of thousands of innocent people and led to the widespread concern of the organization, particularly in light of its connections with the AlQaida and other Jihadists across the world. Thus, African troops mandated by the African Union to support the government of Somalia in the fight against the Al-Shabaab have been deployed to Somalia (AMISOM, 2014). Today, more than 20.000 African Union peacekeeping Missions are active in Somalia, with the approval of the United Nations Security Council. Nonetheless, the effective government was not restored despite many peacebuilding and reconstruction efforts organized by local people and the international community in the last 30 years. Therefore, this article argues that a long-term approach to development, institutional building, and diplomatic strategies will promote peace and political reconciliation in Somalia.

\section{Somali Conflict: Actors and Factors}

At this point, understanding the context of the Somali conflict actors is essential to understand the causes and the consequences of the conflict. The literature on the different actors of the Somali conflict is extensive. For this study, a summary of some of the Somali conflict actors will be discussed. The actors can be grouped into three main players and include, external actors, internal actors, and the militant group Al-Shabaab who are currently active within Somalia. These groups have different political aims, views, and affiliations.

External actors are foreign countries and international organizations that are directly or indirectly involved in Somalia's conflict. According to Bowden (2012), Somalia was divided between Italy, Britain, and France, and another Somali territory was given to Ethiopia or added to Kenyan territory. Italy who colonized Southern Somalia was never in a position to influence events after Somali got its independence. Britain, who also colonized northern Somalia currently known as (Somaliland) walked away and never got involved until recently, mainly when Somali piracy affected the Britain economy and insurance industries. France never became involved in the Somalia conflict but kept its military base in Djibouti. Neighbouring countries such as Ethiopia and Kenya have been Somalia's natural enemies in the last decades.

The Internal actors include federal member states and their foreign allies who have strategic interests in Somalia. Moreover, the current situation in the country confirms that the competition for political power and natural resources sharing between the federal government and federal member states was the leading cause of the conflict in recent years. However, the civil war that started in Somalia in 1991 was motivated by resources and/or political power and clan supremacy. Additionally, the autonomous region of Somaliland is also a big question for the conflict of Somalia to end especially the question of the independence of Somaliland. We argue that the heavily armed conflict and the lawlessness of the country motivated by the clan and clannism movements. We also argue that the civil war broke out in Somalia and the conflicts between rival clans that destroyed the state institutions

${ }^{1}$ African Union Mission in Somalia (AMISOM) is operated by the African Union as a regional peacekeeping mission with the approval of the UN. It was founded on $19^{\text {th }}$ January 2017 at the African Union's Peace and Security Council with an initial six-month mandate. 
were motivated by clan and clannism. We, also consider clan organization as the main enemy against Somalia to establish a modern state and get back to its position in Africa and the world.

\section{Major Causes of the Somali Conflict}

Clan competition: Somalis are well-known as people who lived with hostilities for ages because of the semi-desert geographical location with a scarcity of water and pasture. The reputation of Somalis as fearless defenders of their independence, their reliant faith in Allah, their clans, and the regenerative glory of camels has evolved since Somalia provided fragrance to the ancient Egyptian pharaohs (Peterson, 2014, p. 7). For centuries nomadic pastoralism provided a livelihood to the Somali people in the Horn of Africa, before the colonial partition of the Somali 'territories' in the middle of the 19th century, the history of the region had been dominated by the massive migration of Somalis into areas inhabited initially by other populations (Ahmed \& Green, 1999). The main reason for movements lays looking for livelihoods for families as well as pasture and water for their livestock.

When it comes to the inner lives, Somalis organized and lived as clans that used to have their own rules of living. Before the colonials, the Somali people had no central authority with public interests then groups run for their attention. Traditional Somali politics was based on two dialectically related principles: kinship and contract (tol iyo xeer) (Jama, 2007). Kinship was founded on the segmentary lineage system under which people traced their descent to common male ancestors (Jama, 2007). Agnates are used as mutual political groups since blood relativeness is the bond. However, for a political system, the blood relative remains sufficient. Agnates worked as corporate political groups because they negotiated a social contract that defined the terms of their collective unity (Jama, 2007). Since the land of the Somalis is mainly dry and semi-desert, the Somali clans had been confronting over the ownership of the necessary resources such as water, livestock, and fertile or grazing land prolonged earlier the independence (Elmi \& Barise, 2006; Lewis, 1993). Remarkably, like the onions, the clans contain layers that go more in-depth to two brothers who conflict on their prioritized interest. According to (Peterson, 2014) who noted the hierarchy of priorities from the Somali proverb had this to say:

\section{"Me and my clan against the world; \\ Me and my family against my clan; \\ Me and my brother against my family; Me against my brother".}

This culture of pastoralism mixed with the political changes after the arrival of the colonials. During the celebrations of independence and born of Somali Republic, many poets mentioned their feelings through poems and songs. Among the songs "Aan Maalno Hasheena Maandeeq" (Let us milk our she-camel Maandeeq) written by Sahardiid Mohamed and sung by Abdullahi Qarshe was one of the most famous songs (Hassan, 2008). Analyzing the song, one can argue that it shows how the Somalis would utilize the new government through the personification of the she-camel as the government. Nevertheless, stealing camel using force was one of the primary roots of conflict among Somalis. Following the independence of Somalia urbanization commenced; thus, the kind of resources and means of obtaining them changed. Political figures assumed that whoever is in power would manage the state's resources. Access to water sources and grazing in the Somali rural areas shifted to approaching government institutions, resources, staffing of civil servants and access to foreign aid. According to Ali (2016), a Somali journalist Mohamed Urdoh published his investigative report after he observed the Somali police force in 1967 . He discovered that more than $70 \%$ of police station chiefs were associates of the same clans. He found out that 51 out of 71 polices chiefs were the same clan.

Foreign intervention: The Horn of Africa lies one of the strategically most important places in the world and it's essential for global maritime checkpoints. The strait lies between the African nations of Eritrea, Somalia, and Djibouti, as well as Yemen on the Arabian Peninsula. About 40 per cent of the world's oil vessels cross the Bab el Mandeb, which links the Indian Ocean to the Mediterranean via the Red Sea and Suez Canal (Abdinor H. Dahir, as cited in Davis et al., 2007, Addow, 2016). Some can say that foreign intervention plays a crucial role in the Somali conflict. As far as back to the colonial legacy, Somalis have been under the pressure of foreign countries. The European colonizers (Britain, Italy, and France) divided the land of Somalis into five parts. Britain seized two, Italy and France each took one.

To appease the Ethiopian king Menelik who was greedy for land, Britain gave him the Somali region of Ogaden. From 1891 to the present, Ethiopia has been expanding to the east (Elmi \& Barise, 2006). Somalis settle a strategic place in which foreigners have the intention to utilize. The foreigner's partition of Somalis ignited the raise Somali nationalism and the dream of reuniting the greater Somalia, which contains the five Somalis. As soon as two Somalis that would later be united and formed the Somali Republic got the independence from Britain and Italy was attacked by Ethiopia in 1964. Following that war in 1977, the military regime of Somalia attacked Ethiopia to liberate the Somali Ogaden region of Ethiopia. This war changed and impacted the life of Somalis after the Soviet Union, Cuba, and other countries helped Ethiopia and defeated the Somali army. Following the defeat of the Somali army in the Ogaden War, some of the foreign countries were funding and arming Somali militias against the military government. Lastly, these opposition groups overthrew the military regime after 21 
years in power.

Foreigners support and oppose the conflicting parties in Somali politics based on their interests. The neighbouring countries play an active role in the Somali conflict; Ethiopia and Kenya are the leading countries. Ethiopia's meddling is the most important and persistent factor in the perpetuation of the Somali conflict (Elmi \& Barise, 2006). Ethiopian intrusion plays a key role in the lengthy conflict in Somalia. Elmi \& Barise (2006), argue that Ethiopia was the leading provider of shelter and arms to all plunders, demoralized the two most noteworthy peace understandings (Cairo 1997, and Arta 2000). Correspondingly, it had predisposed the Somali peace process in Kenya, which its outcomes formed the transitional federal government. For direct intervention, Ethiopia invaded several towns in Southern Somalia without the approval of the Somali government and provided weapons to the allied groups across the border. In other words, Ethiopia, a powerful and well-positioned state, is a hostile neighbour that aims to maintain a weak and divided Somalia (Elmi \& Barise, 2006).

Not only neighbouring countries' interventions exacerbated the Somali conflict, but the internationalized intervention also contributed to the prolonged Somali conflict. Until the late 1980s, the world great powers (the United States, and the Soviet Union) used Somalia and its regional neighbours as a play arena for their geopolitical rivalry with no concern for the local consequences. The end of the Cold War removed the competitive motive for U.S. interventionism, its place being first (in the early nineties) taken by a humanitarian motive, couched in terms of the 'new world order,' and then after 9/11 by that of counter-terrorism (Møller, 2009). Even though the former rationale was altruistic and the latter selfish, the consequences were not all that different, both being profoundly counterproductive, and exacerbating, rather than relieving, the plight of the Somali population (Møller, 2009). The foreign intervention has been frustrating peace efforts in Somalia and triggers more thorny confrontations. The level of forceful military engagement intended for regional domination has profoundly affected the efforts of peacebuilding and state-building in Somalia negatively (Mohamed Haji Ingiriis, 2018).

Radical Extremism: Somalia is a kind of country where culture is almost identical with the religion. The Islamization of the Somali peninsula was gradual through assimilation and cultural infusion (A. M. Abdullahi, 2015 , p. 86). As Somalis faithfully practise the Islamic religion, it is easy-going to manipulate to extremism ideology. The religious groups had been secretly operating since the military regime. The military brutality caused the Islamists to remain less active in politics. Nevertheless, as soon as the military regime collapsed in 1991, the radical Islamists armed themselves and joined the conflict. Al-Ittihad Al-Islam (AIAI), a neo-Salafist group that revealed itself in 1992 in the United Kingdom, joined the conflict and conquered some regions in Somalia to implement its aim. The first of its published eight objectives is the establishment of the Islamic State and others include the rejection of all Jahili (un-Islamic) polity, the attainment of Islamic justice, the establishment of peace in society, a well-planned economy, propagation of Islam, and war against all devious beliefs, Bida (A. Abdullahi, 1992, p. 114).

The armed wing of Al-Ittihad Al-Islam (AIAI) faced many clashes against the Somali warlords and Ethiopia in the Somali region of Ethiopia in the 1990s. The skirmishes ignited the defeat of Al-Ittihad Al-Islam, and Ethiopia invaded Somalia for the first time. This unusual reaction to invading Somalia was the outcome of a series of deadly explosions, and assaults occurred in the capital Addis Ababa whose responsibility was claimed by Al-Ittihad spokesman in Mogadishu (Mohamed Haji Ingiriis, 2018). The defeat of Al-Ittihad did not pave the way the vanish of extremist ideology; instead, it leads to its reshaping. Somalia experienced years of rules under warlords, mainly in Southern regions. Similarly, extremists were also running their operations. Somalia attracted international terrorists and became a hub for some of the most wanted international terrorists, including those who were accused of the explosions of the U.S. embassies in East Africa.

Massive Corruption: Since 1960 independence, Somalia has been a victim of corruption in government institutions. During the so-called democracy years of civil government (1960-1969), corruption grew up along with the Somali government and the population disgusted beyond the endurance of corruption and wished a political change that would implement reforms. The inappropriateness of the Italian-style parliamentary form of government served to foster widespread corruption (Payton, 1980a). According to Payton (1980a), corruption, favouritism, and nepotism reached a peak during the first nine years of the Somali republic. The corruption laid down the cornerstone of the conflict among the clans. Politicians using Somali clans began competing for the public resources for private good. On the other hand, government officials spent thousands of public funds to manipulate the elections for their interests. It was noted, "that the price of Somali politics that between January and October 1969, the Office of the Prime Minister reportedly dispensed $£ 500,000$ in public funds to members of the National Assembly which 'had been turned into a sordid marketplace where deputies traded their votes for a personal reward with scant regard for the interests of their constituents" (Payton, 1980b). The increasing level of corruption and maladministration that dominated the 1960-1969 Somali republic was the main reason why the army drew widespread popular support (Tripodi, 1999, p. 114). Although the military regime showed intolerance to the corruption during the early years of reign, later it only got worsened and widespread. Corruption impacted every single institution in the military regime. It paved the way grievances of many clans that opposed the military government and prompted the early stages of the Somali conflict. Sheikh Mukhtar, the most senior parliamentarian 
of the last civilian administration, not without overstating his point labelled Siad Barre for becoming ' $m u s u q$ maasuq (corruption) (Ingiriis, 2016, p. 131).

Currently, Somalia remains the top of the most corrupt states on the globe. According to Transparency International (2019), Somalia ranked 180/180. Somalia has indicated the most corrupted state in the world and scored only $9 / 100$ free from corruption. As one of the most prolonged states collapses in recent decades, Somalia experiences significant corruption challenges that are common among conflict-torn countries. Like previous years, many of the countries near the bottom of the 2018 Corruption Perceptions Index have been severely affected by violent conflict in recent years (Transparency International, 2019). Corruption is further worsened by the fragility of the central government, limitedness of administrative strength, lack of enough resources, feeble leadership structures and an inadequate ability to pay government officials. Major public and private institutions like security forces, judiciary, immigration management, land administration, public procurement, and legislation are always involved in allegations of corruption. The corruption in public institutions contributes to the sustainability of the Somali conflict. For instance, security forces who were supposed to stabilize the country and combat the AlShabaab extremists' attacks tend to sell their armies to their opponents.

Moreover, security forces leaders embellish the number of the armies they command to earn the salaries of nonexistent armies. Contrarily, the informal sector that the Somali economy relies on, such as livestock trades, telecommunications, and remittances fuels to corruption by not paying the required taxes to the government probably. The consequences of private sector corruption trigger competition among them, which leads to the manipulation of government officials - the flimsiness of government officials to the businessmen fuels the Somali conflict into new layers. According to Freedom House, 2012, estimated money of more than $\$ 72$ million in donor fund was corrupted in between 2009 and 2010, whereas, an additional \$250 million in incomes were in ambiguity transactions. Thus, it is accepted that corruption and conflict are frequent. Consequently, there is an integrative relationship between conflict and corruption as corruption feeds on conflicts and vice versa. Generally speaking, corruption is an essential cause of conflict, weakening the government and causing grievances and discontent (Giorgio Spagnol, 2019).

The militarization of clan members: The opposition forces that ousted Mohamed Siad Barre had organized into clans, and each of them represented the interests of a specific clan. Following the collapse of the military government in 1991, clans went back to their origins and prepared themselves to protect their affiliates and attain their interests. The resettlement of clans in a specific piece of land draws clan-based borders, and those borders cause a conflict between the clans. The main concerns that reason those conflicts, including water and pasture for livestock in rural areas. The members of the clan, leading youth, are militarized and funded. The clan militaries show loyalty to their clans and ready to die for the name and prestige of the clan. The accessibility of weapons facilitates the militarization of clans in Somalia. The military regime mainly focused on defence, built a strong army, and compelled the so-called national duty program "Shaqo-Quran." While preserving his monopoly of arms, Siad Barre tried to spread the military ethos through military training courses required for school and college graduates as well as civil servants (Adam, 1992). The main aim of the program was the provision of military training to Somali citizens to defend the country if needed. It has been noted "that from 1969 onwards the Somali military budget continued to absorb an increasing proportion of national revenue; 'even before the war, Somalia was the only country with a per capita income of less than $\$ 150$ which spent huge sums on armaments and defence' (Samatar, 1988:114)" (Adam, 1992). Consequently, the fall of the military regime, the whole weapons, went to the hands of clans, then each clan established its militias. Presently, there are harsh confrontations between the clan militias, which claims the lives of hundreds of innocent Somalis. The militarized clan militias extend the lifetime of the Somali conflict.

Political, Economic and Social Inequalities: The political, economic, and social inequalities played a crucial role in intensifying the Somali conflict. Some clans gained more political power than others and utilized the scarce economic opportunities for their private good. The political, along with economic disparities, resulted in social inequality. The Gini index, a measure of inequality, in Somalia was 34 per cent in 2017 (World Bank Group, 2019). Layers of Somali inequality triggers grievances and grudges of some people, and their reaction contributed to the urgency and sustainability of conflict.

Nevertheless, the political, economic, and social inequalities are less discussed and ignored to find a solution for it. As long as those factors remain, the conflict grows and extends its existence. For countries like Somalia that are struggling for stability in all sectors, such as, economic, political, social, and cultural, always have to take into account of addressing the inequality that exists among larger groups of people, here, in this case, the clans in Somalia (Muse, 2019). Two approaches exist to explain why inequality exists: one is to blame the poor; other is to blame society. Some parts of Somali communities were not provided opportunities to improve themselves in terms of education, health, and other social services; thus, a massive number of those people mainly youth found limited options and armed themselves to play their roles in the conflict.

Extreme Poverty and High Unemployment: Somalia is one of the poorest countries in the world. The World Bank Group (2019), published that $69 \%$ of Somali people lived in poverty in 2017. Somalia has the sixth-highest 
poverty rate in the region, only after the Democratic Republic of Congo, Central African Republic, Madagascar, Burundi, and South Sudan (World Bank Group, 2019). The extreme poverty is a consequence of high unemployment in the country. The population aged 15-64 years comprised just above half (52.3\%) of the total population (UNFPA, 2014). The population in the workforce, especially youth, hardly finds proper employment. The unemployment leaves an idle person a vulnerability to join conflicting parties. Extreme groups and other actors of the Somali conflict utilizes the eagerness of vulnerable groups and promises provision of some wages and salary.

\section{The Consequences of the Somali Conflict}

Mass Migration: One of the significant consequences of prolonged Somali conflict is that it caused massive displacement and migration, forming the fourth biggest refugees globally. Some Somalis migrated before the fall of the military regime. However, most of the exiles left the country during the break out of the civil war as refugees. This mass migration started in the northern regions (currently Somaliland) in late 1988 and followed by the southern provinces in 1991 when the fight against the military regime turned fierce into a civil war. In the 1990s, there were 478.3 thousand Somali immigrants worldwide compared to 20.7 thousand in 2005 and 52.1 thousand in 2019. In 1990, data exhibits $6.6 \%$ of international migrants were Somalis, the number decreased to $0.2 \%$ in 2005 and increased again to $0.3 \%$ in 2019 (UN DESA, 2019).

The Somali migration took several forms, some migrated to Europe, North America, and Arabian countries, as well as others, immigrated to neighbouring countries. The Somali migrants faced many challenges in adapting and living those new countries, including discrimination, humiliation, and racism (Abdulle, 1999; Fangen, 2006; Magan, 2019; Nimo-Ilhan, 2016). Moreover, there are hundreds of thousands of Somalis fled to the neighbouring countries, mainly Kenya, Ethiopia, Djibouti, and some in Yemen. These refugees have been living in severe conditions since today. The accommodation for Somali refugees who fled the civil war, famine and drought ignited the establishment of Dadaab refugee in 1991. The camp was constructed in the northeastern Kenyan region. However, the Somali refugees outnumbered and overcrowded the camp. Recent data indicate that the current population of Dadaab camp $(463,422)$ is more than five times the camp's recommended initial capacity of 90,000 people (Kumssa et al., 2014). The Somali refugees face harsh obstacles for obtaining adequate shelter, water, education, health that are necessary for living needs.

Violent Extremism: Extremism is an international issue that has been growing for the last three decades. Extremism based on a misinterpretation of religion comes to Somalia as one of the main consequences of the Somali conflict. After the collapse of the military regime in 1991, religious motivated and rebel groups emerged in Somalia. Since there was no or less effective functional government in Somalia, different religious groups came to the political arena. The urgency of radical groups in Somalia publicly waxed in 1991 and the most prominent groups among Al Ittihad Al Islami, Al Tabligh, and Al Islah. In 1995, a group called Jihad Al Islam, led by Sheikh Abbas bin Omar, emerged in Mogadishu and gave the two main warlords, General Mohammed Farah Aideed and Ali Mahdi, an ultimatum to end their factional fighting (Dagne, 2012). The group mentioned their presence in several countries, including Sudan, Pakistan, Yemen, and Kenya, as well as having their offices in those countries. In 1996 some members of the group formed a club named Sharia (Islamic law) Implementation Club (SIC). SIC's principal objective was to establish Sharia courts throughout the country (Dagne, 2012). According to Dagne (2012), vital players in the foundation of these courts were also members of the Transitional National Government of Somalia.

The trends of radical Islamists turned into the current fiercer Al-Shabab, who declared affiliation with AlQaeda in 2012. Most influencing Al-Shabab founders were related to Al-Qaeda pieces of training and visited Afghanistan. Besides, foreign radical Islamists made Somalia a hiding place and worked hard to implement their political ideologies. In 2003, the leadership of Al-Ittihad, including Sheik Ali Warsame, brother in law of Sheik Hassan Aweys and some other top leaders, met and later decided to form a new political front (Dagne, 2012). However, the young active members of Al Ittihad, with their independent political motive, declined the proposal and agreed to form their group. The young extremists met in Las-anod, and some members of the group shared a mutual experience, fighting in Afghanistan. The young extremists founded al Harakat Al-Mujahedeen, recently known as Al-Shabaab. The main contributors to the formation of the group including, the dead leader of AlShabaab, Ahmed Abdi Godane, the late Aden Hashi Ayrow, the renegade Mukhtar Robow and Ibrahim Haji Jama. The primary objective of this group was irredentism and to establish a "Greater Somalia" under Sharia (Dagne, 2012). However, Al-Shabaab remained ineffective with no land under their control until 2008.

The extensive Somali conflict attracted international terrorists and made Somalia a hub for international terrorists. Those terrorists, including some of the most wanted terrorists who were accused of bombing U.S. embassies in East African countries, Kenya and Tanzania in 1998. The suspects operated beside other Somalis including Fazul Abdullah (also known as Harun Fazul) from Comoros- who was the mastermind of the 1998 U.S. embassy bombings in Kenya and Tanzania, Sheik Mohamed Abu Faid, Saudi national, Abu Mansur Al Ameriki, American national, Abu Musa Mombasa, Pakistani national, Mohamoud Mujajir, Sudanese national, Abu 
Suleiman Al-Banadiri, Somali of Yemeni descent (Dagne, 2012; Harun Maruf \& Joseph, 2018). The new concern of terrorism in Somalia caused the death of thousands of people, mass destruction, and different casualties. The terrorists extended their operations to the East African countries, mostly Kenya, in which several terrorist attacks were carried out, and this came after the decision of deploying Kenyan forces in Somalia in 2011. Likewise, Uganda has most of the AMISOM peacekeeping forces in Somalia. In 2010, Ugandan civilians, watching the final World Cup match, were bombed in Kampala.

In Somalia, where people are suffering most, the Al-Shabaab terrorists carry out attacks indiscriminately through car bombs, grenades, shelling/ artillery, abduction, remote explosive, landmine, and attacks. Between 1st January 2010 - 4th January 2020, Somalis have been experiencing one of the worst terrorist attacks on the globe. In the decade, the number of organized violent events was 10,811, and the reported fatalities were 29,593. Still, moreover that, the civilians are also targeted. In the same decade, civilians were targeted in 1752 events, with 3650 reported fatalities. Al-Shabab also carried out attacks in Kenya, targeting both armies and civilians starting from 2011 when Kenyan forces entered Somali to fight against Al-Shabaab. Al-Shabab took 416 organized violent events in Kenya, which caused 1484 reported fatalities, and they also targeted civilians in 156 times, with 761 fatalities (ACLED, 2020). In addition to Al-Qaeda linked Al-Shabaab, there are renegade terrorists that separated from Al-Shabaab and declared that they are allied with ISIS international terrorists. The terrorists see Somalia as a suitable place for hosting terrorism because of the absence of persuasive central authority besides the availability of weapons and much-unemployed youth that can be recruited as fighters. The different terrorist groups clashed each other several times. The conflicts between the terrorist groups are just a symbol that shows there is no unique ideology among them but different political ambitions.

The emergency of Piracy: Piracy has been an existing problem back to hundreds of years and took several stages depending on the situations of that moment. Piracy stands as one of the main consequences of the Somali conflict. The reason that contributed to the urgency of piracy is an absence of a functional government in Somalia for almost decades. Some arguments mention piracy as a reaction of Somali fishers confronting foreigner fishing in Somali waters illegally. The root cause of Somali piracy lies in the threat that illegal fishing posed to the livelihoods of subsistence and commercial fishers along the coastline (Awet Weldemichael \& Hassan, 2012). Whatever the causes could be either overfishing of foreigner or the greedy Somali pirates, the fall of the Somali government is what mothers all those consequences.

The piracy adversely impacts international countries as well as Somalis. Since the early 1990s, rampant piracy off the coast of Somalia has become a major issue for global trade and security, prompting strong responses from the international community (Kellerman, 2011). As back as the 1990s, the urgency of piracy off the Somali coast challenged the international trade and security rising reactions from the global communities. In 2010 alone, the collective cost of ransom money, military protection, and cargo insurance as a result of piracy is estimated to have been between 7 and 12 billion dollars (Kellerman, 2011). Contrarily, Somali communities experienced various negative impacts of piracy, primarily the behaviour of the pirates. Pirate presence in coastal villages and inland towns tended to be closely followed by a deterioration of security, economic challenges, and the erosion of Islamic religious tenets and Somali moral values (Awet Weldemichael \& Hassan, 2012). The increase in consumption of drugs mainly, khat, alcohol, cigarettes, and other drugs leaked into society, leading in some drunk gun-wielding youth firing at random and untrained drivers with luxurious cars with the maximum speed that causes serious accidents. Additionally, prostitutions augmented as did failed marriages and broken families. Buying on credit, pirates started to pay twice the regular price of goods, leaving ordinary people hard-pressed to sustain their lives due to the exorbitantly inflated prices of basic consumer goods (Awet Weldemichael \& Hassan, 2012).

Loss of Somali Unity and Nationalism: Nationalism has been a vital force for the development of a nation. However, considering the Somali nationalism which came into existence as resisting force aimed to unite Somalis and respond to the colonial powers during the early $20^{\text {th }}$ century. Also, nationalism became more political force during the establishment of the Somali state and declined during the beginning of the civil war. The Somali conflict has an unenthusiastic correlation with nationalism. The early stages of the conflict started with grievances and grudges, leading to a decline in the sense of patriotism. The development of the Somali conflict weakened nationalism through times and finally caused the end of the central government. Consequently, other unnecessary loyalties, tribalism, and extremism took the role of nationalism.

The main centrifugal forces in Somali society revolve around clans - essentially genealogies that trace descent from common male ancestors (tolnimo) (Solomon, 2014). Tribalism, the main contributor to the Somali conflict, shows intense rivalry to the nationalism. Thus, the shared Somali nationalism is weakened by state-based nationalism rooted in the clan-based federal states. Thus, the conflict shapes the tribalism, which plays the role of nationalism and develops each clan in uniting among them and defending their interests instead of national interest. Religious nationalism, the result of radical extremist interpretations, managed to unite people of different clans, races and even nationalities in Somalia. The radical groups created a convincing alternative to the Somali nationalism and shifted to extreme Islamic nationalism. There are indications that Al Shabaab is picking up the mantle of al-Ghazi and Hassan and attempting to merge patriotism (specifically the dream of 'Greater Somalia') 
with a radical Islam (Solomon, 2014). This group is against the government in Somalia and regard it as infidels against the Islamic culture and promised to fight against it. Thus, signs of nationalism are life-threatening redlines in the eyes of this group. The Somali government, meanwhile, is referred to as kooxda ridada (the apostate group), and the derogatory name Al Shabaab gives to the Mogadishu government is Daba Dhilif (meaning a government set up for a foreign purpose) (Solomon, 2014).

\section{Strategies for Inclusive Peace-building}

Peace-building has developed tremendously in the last three decades and has grown over time to assume different meanings from different organizations and policy practitioners in different contexts. However, the term 'peacebuilding' came into widespread use after 1992 when the Secretary-General, Boutros Boutros announced an 'agenda for peace' since then, peacebuilding has come to be understood as an essential concept reflecting a longterm approach to peace, security, and development. In Somalia for instance, the last 20 years, the international community has been supporting Somalia to recover from civil war and violent conflict, yet, these efforts have not produced the desired results since the peacebuilding approach was a top-down process. A review of literature has shown that most peacebuilding approaches for Somalia have been focusing on one top-down approach, such as the promotion of democracy, elections, free marked based reforms and building local institutions allied with modern state standards adopted by the international community. Thus, this approach has failed to promote peace and stability in Somalia. Therefore, to address Somalia's prolonged conflict and to carry forward positive outcomes of previous peacebuilding efforts. We suggest the following strategies to be adopted.

Social reconciliation: Over the past years, Somalia has experienced civil wars, enter-clan conflicts, warlords, the rise of extremism and radicalization, and a devastating famine - leading to a loss of the state institutions, social cohesion, and unity among the Somali people. Thus, there is an urgent need that the government of Somalia and its federal member states undertake a deep-rooted process of social reconciliation across the country from the village level to the city, and from the regional level to the national level. So, it is equally essential that the reconciliation process to held in Somalia, leading by local people in terms of both leadership and financially. Furthermore, we recommend that an independent national institution to be established to facilitate and organize the process of the national reconciliation process.

Traditional peacebuilding techniques: We consider the traditional peacebuilding approach as an important way of resolving the Somalia conflict. This approach focuses on issues of human dignity, human rights promotion, and respect for each other (Abiodum, 2000; Mabovula, 2011; Swidler, 1992). Moreover, this traditional peacebuilding approach involves norms, ideas, dialogues, and other African traditional methods developed by African traditional societies (Bamidele, 2014). Thus, Somalis traditional elders need to be given space in conflict resolution and the state-building process in Somalia. It also promotes the ownership of peacebuilding efforts, which can connect people to a collective identity such as "peace". We, therefore, recommend that traditional leaders be given a formal role in the peacebuilding process. Nonetheless, we believe the traditional peacebuilding approach as a tool for peacebuilding can help the bottom-up peacebuilding approach to stand more successful. Somaliland and Puntland are good examples of how this approach could work in Somalia. In Somaliland, for instance, traditional elders managed to bring people together to establish a society with a common interest and build peace from the ground. Furthermore, the traditional elders successfully implemented a social reconciliation followed the establishment of a framework for peaceful coexistence between the different clans living in Somaliland. Among the achievement of the conferences in Burao and Borama with the leadership of the traditional elders, Somaliland created a presidential system of government compromising two houses: a clan elders house and an elected house of the representative. Thus, Somalialdn established a relatively strong local community structures that had been successful since the days of British rule. (Leweis, 2002) Nevertheless, traditional elders played a similar but lesser role in Puntland, where clan negotiations took place under the dominance of a single, Ethiopian-supported warlord (Leonard \& Samantar, 2011). However, the understanding of those clan leaders produced a peaceful coexistence and stability in the Puntland regions. Considering, the twenty-first century events one can agree how difficult is for an external actor to involve in conflicts and look for a resolution. The collective power of international actors seems a tempting alternative, but it is naïve to assume that the various national and multinational interests of the actors who would be involved are all either consistent with one another or congenial to a domestically viable statebuilding project (Leonard \& Samantar, 2011). Therefore, we consider if the traditional peacebuilding approach is well implemented will ensure continuity of peacebuilding efforts from the local level as well as promote collective integrity and social responsibility of the people.

Governance and institutional building: We consider the problem of governance as one the core and fundamental source of Somalis political instability. The Somalis political elite do not agree on how and who is going to govern the country and all the tensions and problems of governance undermined Somalis willing to build a good governance environment. Furthermore, the absence of political institutions and poor good governance practices in Somalia is considered to be one of the significant challenges facing the Somalis peacebuilding and reconstruction process. Governance, according to Viteritti (2009) refers to an institutional arrangement that assigns power to the 
public institutions and officials to define the mechanisms by which the society can hold them an accountable and transparent way. Governance further involves the mechanisms, processes, and institutions that citizens, groups, and societies utilize in joint decision-making and implementations in expressing their interest and in fulfilling their obligations as well as solving their differences. Governance leads to the nature of mutual interaction among social actors like, civil society organization, the society, political parties as well as bureaucracy, and the state, which simply meant "joint government". A governance system that society believes and strong institutions is what Somalia has lacked for the last 30 years. According to Elmi \& Barise (2006), abuse of power is one of the main and core causes of the Somali conflict. Therefore, creating a good governance environment and building strong institutions that can regulate the exercise of power is crucial for building peace in Somalia (Hared, 2018).

Inclusivity for peacebuilding and sustaining peace: The term inclusion is of increasing importance as it is used by the states, regional and international organizations to promote peace. Inclusion is also crucial for creating an environment where all citizens can equally be able to contribute efforts to sustain peace and development, with an emphasis on including those who may be marginalized within the society. Additionally, the Inclusive peacebuilding processes are a key and fundamental way of ending violent conflict. Therefore, in the order peacebuilding process in Somalia to be effective, the process must be inclusive and participatory. Furthermore, to sustain the peacebuilding process, it is crucial that no one is left behind, and no one should be subject to any form of exclusionary rhetoric.

\section{Conclusion}

The main theme of this article was to examine the major causes and consequences of the Somali conflict. The article also assessed strategies to peacebuilding and Somalia reconstruction. Accordingly, the article found that the ongoing conflict in Somalia has interrelated causes that include instrumentalization of clan identities, power struggle, corruption, militarization of clan militia, political, economic and social inequalities, and extreme poverty and high unemployment. Moreover, the article analyzed the consequences of the conflict in Somalia and found that mass migration, loss of Somali unity and nationalism, violent extremism, and emergency of piracy are the outcomes of the conflict. Nonetheless, the conflict in Somalia is not limited to the country rather have regional consequences including, political, economic and humanitarian consequences. In the final section of this article, we proposed inclusive peacebuilding strategies that we believe would help Somalia to get back its position in Africa and the search for peace and long-term stability.

\section{REFERENCES}

Abbink, J., Ellis, S., \& van Kessel, I. (2009). Movers and Shakers: Social Movements in Africa: Vol. null (null (ed.)).

Abdi, M. A. (2012). Conflict resolution and nation-building in Somalia. Xlibris Corporation.

Abdullahi, A. (1992). Tribalism, Nationalism and Islam: The Crisis of Political Loyalty in Somalia (Issue November). http://digitool.library.mcgill.ca/webclient/StreamGate?folder_id=0\&dvs=1548104435806 165

Abdullahi, A. M. (2015). The Islamic Movement in Somalia: A Study of the Islah Movement, 1950-2000. In ProQuest Dissertations and Theses. Adonis \& Abbey Publishers Ltd. https://search.proquest.com/docview/902520351?accountid=9645

Abdulle, M. H. (1999). Somali immigrants in Ottawa: The causes of their migration and the challenges of resettling in Canada.

Abiodum, R. (2000). A history of art in Africa (Preface). A History of Art in Africa. Upper Saddle River: Prentice Hall.

ACLED. (2020). Political Violence Involving Alshabab. ACLED RESOURCES: AL SHABAAB IN SOMALIA AND KENYA. https://www.acleddata.com/2020/01/15/acled-resources-al-shabaab-in-somalia-and-kenya/

Adam, H. M. (1992). Somalia: Militarism, Warlordism or Democracy? Review of African Political Economy, 19(54), 11-26. http://www.jstor.org/stable/4006165

Addow, S. S. Y. (2016). Somalia Security Shaping Factors: Colonial Legacy, Global Conflicts and State Making Process. Somali Studies, 1, 105-117.

Ahmed, I. I., \& Green, R. H. (1999). The Heritage of War and State Collapse in Somalia and Somaliland: LocalLevel Effects, External Interventions and Reconstruction. Third World Quarterly, 20(1), 113-127. http://www.jstor.org/stable/3993185

Ali, Z. (2016). Cataclysm Secrets of the Horn of Africa.

AMISOM. (2014). African Union Mission in Somalia. AMISOM MANDATE. http://amisom-au.org/amisommandate

Avis, W., \& Herbert, S. (2016). Rapid fragility and migration assessment for Somalia. Birmingham: GSDRC University of Birmingham.

Awet Weldemichael, \& Hassan, A. (2012). Somalia: Understanding Somali Piracy on Land and Sea. Global Policy Forum. 
Bamidele, O. (2014). African indigenous system of conflict resolution: Reference to the case of Rwanda and Somalia. Peace Studies Journal, 7(2), 11-28.

Bowden, R. (2012). Internal and external influences on Somalia's civil war. Peace Insight. https://www.peaceinsight.org/blog/2012/06/internal-external-influences-somalia-war/

Clark, J. (1993). The debacle in Somalia: failure of the collective response. Enforcing Restraint: Collective Intervention in Internal Conflicts. New York: Council on Foreign Relations.

Dagne, T. (2012). Somalia: Current conditions and prospects for a lasting peace. In Economic, Political and Social Issues of Africa. Diane Publishing.

DiPrizio, R. C. (2002). Armed humanitarians: US interventions from northern Iraq to Kosovo. JHU Press.

Elmi, A. A. (2010). Understanding the Somalia conflagration: Identity, political Islam and peacebuilding. Pluto Press.

Elmi, A. A., \& Barise, A. (2006). The Somali Conflict: Root causes, obstacles, and peace-building strategies. African Security Studies, 15(1), 32-54.

Fangen, K. (2006). Humiliation experienced by Somali refugees in Norway. Journal of Refugee Studies, 19(1), 69-93. https://doi.org/10.1093/jrs/fej001

Freedom House. (2012). Freedom in the World Country report. http://www.freedomhouse.org/report/freedomworld/2012/somalia

Giorgio Spagnol. (2019). Correlation Between Conflict and Corruption.

Hared, A. (2018). The challenges of good governance practices in Somalia. Ankara Yildirim Beyazit University. Harper, M. (2012). Getting Somalia Wrong?: faith, war and hope in a shattered state. Zed Books Ltd.

Harun Maruf, \& Joseph, D. (2018). Inside Al-Shabaab: The Secret History of Al-Qaeda's Most Powerful Ally. In Inside Al-Shabaab. Indiana University Press. https://doi.org/10.2307/j.ctv6mtfn2

Hassan, M.-R. S. (2008). Interview with the late Abdullahi Qarshe (1994) at the Residence of Obliqe Carton in Djibouti. Bildhaan: An International Journal of Somali Studies, 2(1), 5.

Ingiriis, M H. (2016). The Suicidal State in Somalia: The Rise and Fall of the Siad Barre Regime, 1969-1991: Vol. null (null (ed.)).

Ingiriis, Mohamed Haji. (2018). From Al-Itihaad to Al-Shabaab: how the Ethiopian intervention and the 'War on Terror' exacerbated the conflict in Somalia. Third World Quarterly, 39(11), 2033-2052. https://doi.org/10.1080/01436597.2018.1479186

Jama, M. (2007). Kinship and Contract in Somali Politics. Africa, 77(2), $226-249$. https://doi.org/10.3366/afr.2007.77.2.226

Kellerman, M. G. (2011). Somali Piracy: Causes and Consequences. In Inquiries Journal/Student Pulse (Vol. 3 , Issue 09). http://www.inquiriesjournal.com/a?id=579

Khayre, A. A. M. (2017). Somalia: making human rights central to the state rebuilding. Conflict Studies Quarterly, 21.

Kumssa, A., Williams, J. H., Jones, J. F., \& Des Marais, E. A. (2014). Conflict and migration: The case of Somali refugees in northeastern Kenya. Global Social Welfare, 1(4), 145-156.

Leonard, D. K., \& Samantar, M. S. (2011). What Does the Somali Experience Teach Us about the Social Contract and the State? Development and Change, 42(2), 559-584. https://doi.org/10.1111/j.1467-7660.2011.01702.x

Lewis, I. M. (200), A modern history of Somalia, $4^{\text {th }}$ edition. University of Ohio Press, Athens 200.

Lewis, I. M. (1980). A Modern History of Somalia: Nation and State in the Horn of Africa. Longman. https://books.google.com.tr/books?id=ZtxyAAAAMAAJ

Lewis, I. M. (1993). Understanding Somalia: a guide to culture, history and social institutions. Haan Pub.

Mabovula, N. N. (2011). The erosion of African communal values: a reappraisal of the African Ubuntu philosophy. Inkanyiso: Journal of Humanities and Social Sciences, 3(1), 38-47.

Magan, fresh M. (2019). On Being Black, Muslim, and a Refugee: Stories of Somalis in Chicago. Journal of Immigrant and Refugee Studies. https://doi.org/10.1080/15562948.2019.1617451

Menkhaus, K. (2007). The crisis in Somalia: Tragedy in five acts. African Affairs, 106(424), 357-390.

Møller, B. (2009). The Somali conflict: The role of external actors (Issue 2009: 03). DIIS report.

Mulugeta, K. (2010). The role of regional and international organizations in resolving the Somali conflict: the case of IGAD.

Muse, H. A. (2019). The Political Crisis in Somalia and the Clan System: A Sociological Review of News Media Analyses. Minnesota State University.

New York Times. (1993, September 23). 3 Killed as U.S. Chopper Is Shot Down in Somalia. New York Times. https://www.nytimes.com/1993/09/25/world/3-killed-as-us-chopper-is-shot-down-in-somalia.html

Nimo-Ilhan, A. (2016). Going on Tahriib: The causes and consequences of Somali youth migration to Europe. In Rift Valley Institute Research Paper 5. http://riftvalley.net/publication/going-tahriib\#.WldP16h19PZ

Payton, G. D. (1980a). The Somali Coup of 1969: The Case for Soviet Complicity. The Journal of Modern African Studies, 18(3), 493-508. https://doi.org/10.1017/S0022278X00011629 
Payton, G. D. (1980b). The Somali Coup of 1969: The Case for Soviet Complicity. The Journal of Modern African Studies, 18(3), 493-508. http://www.jstor.org/stable/160366

Peterson, S. (2014). Me against my brother: At war in Somalia, Sudan and Rwanda. In Me Against My Brother: At War in Somalia, Sudan and Rwanda. Routledge. https://doi.org/10.4324/9780203902905

Prendergast, J., \& Thomas-Jensen, C. (2007). Blowing the Horn. Foreign Affairs, 86(2), 59-74. http://www.jstor.org/stable/20032284

Samatar, A. I. (2016). Africa's First Democrats: Somalia's Aden A. Osman and Abdirizak H. Hussein. Oxford University Press.

Solomon, H. (2014). Somalia's Al Shabaab: Clans vs Islamist nationalism. South African Journal of International Affairs, 21(3), 351-366. https://doi.org/10.1080/10220461.2014.967286

Swidler, L. J. (1992). The meaning of life at the edge of the third millennium. Paulist Press.

Transparency International. (2019). Corruption Perception Index. Country Data: Somalia. https://www.transparency.org/en/countries/somalia

Tripodi, P. (1999). The colonial legacy in Somalia: Rome and Mogadishu: from colonial administration to Operation Restore Hope. Palgrave Macmillan. https://doi.org/10.1057/9780333982907

UN DESA. (2019). International Migrant Stock 2019 : Country Profile Somalia.

UNFPA. (2014). Population Estimation Survey for the 18 pre-war regions of Somalia. https://somalia.unfpa.org/sites/default/files/pub-pdf/Population-Estimation-Survey-of-Somalia-PESS-20132014.pdf

Viteritti, J. P. (2009). Why governance matters. When Mayors Take Charge: School Governance in the City, 115.

World Bank Group. (2019). Somali Poverty and Vulnerability Assessment: Findings from Wave 2 of the Somali High-Frequency Survey. 